\title{
Relationships Between Positive and Negative Affect and the Five Factors of Personality in a Brazilian Sample ${ }^{1}$
}

\author{
Cristian Zanon ${ }^{2}$ \\ Universidade São Franciso, Itatiba-SP, Brazil \\ Micheline Roat Bastianello \\ Juliana Cerentini Pacico \\ Claudio Simon Hutz \\ Universidade Federal do Rio Grande do Sul, Porto Alegre-RS, Brazil
}

\begin{abstract}
Strong associations of Neuroticism and Extraversion with positive affects (PA) and negative affects (NA) have been reported in the international literature. This study aimed to evaluate the occurrence of such relationships in a Brazilian sample, and also to investigate the role of Conscientiousness, Agreeableness and Openness in the prediction of PA and NA through the use of a hybrid structural model. Participants were 319 university students, between 17 and 37 years of age (mean $=21.5, S D=4.9$ ). Approximately $64 \%$ of the students were female and $36 \%$ male. Results showed that Neuroticism was the most important predictor of PA and NA, followed by Conscientiousness, but not Extraversion. Surprisingly, Agreeableness was shown to be a weak prediction for NA, but had no relationship with PA. As expected, Openness showed no relationship with PA or NA. These results are partially in agreement with the international literature but some important differences were detected.
\end{abstract}

Keywords: personality, affect, well-being, big five, neuroticism

\section{Relações Entre Afetos Positivos e Negativos com os Cinco Fatores da Personalidade em uma Amostra Brasileira}

\begin{abstract}
Resumo: Fortes associações entre Neuroticismo e Extroversão com afetos positivos (AP) e negativos (AN) têm sido verificados na literatura internacional. Este estudo tem por objetivo avaliar a ocorrência dessas relações em uma amostra brasileira e também investigar o papel de Realização, Socialização e Abertura na predição de AP e AN através de um modelo estrutural híbrido. Participaram do estudo 319 estudantes universitários com idades entre 17 e 37 anos (média $=21,5, D P=4,9$ ). Aproximadamente $64 \%$ dos estudantes são mulheres e 36\% homens. Resultados mostraram que Neuroticismo foi o preditor mais importante de AP e AN, seguido por Realização e não por Extroversão. Surpreendentemente, Socialização apresentou pequena predição sobre AN e nenhuma relação com AN. Como esperado, Abertura não apresentou relação com AP e AN. Estes resultados estão parcialmente em acordo com a literatura internacional, mas algumas diferenças importantes foram verificadas.
\end{abstract}

Palavras-chave: personalidade, afeto, bem-estar, big five, neuroticismo

\section{Relaciones Entre Afecto Positivo y Negativo con los Cinco Factores de Personalidad en una Muestra Brasileña}

\begin{abstract}
Resumen: Asociaciones fuertes de Neuroticismo y Extraversión con afectos positivos (AP) y negativos (AN) han sido reportados en la literatura. Este estudio tuvo como objetivo evaluar la ocurrencia de este tipo de relaciones en una muestra brasileña, y también investigar el papel de la Responsabilidad, Socialización y Apertura en la predicción de los AP y AN a través del uso de un modelo estructural híbrido. Los participantes fueron 319 estudiantes universitarios, entre 17 y 37 años de edad (promedio $=21,5 ; D E=4,9$ ). Alrededor del $64 \%$ de los estudiantes eran mujeres y $36 \%$ hombres. Los resultados mostraron que el neuroticismo fue el predictor más importante del AP y AN, seguido de Responsabilidad, pero no Extraversión. De manera sorprendente, Socialización reveló predicción pequeño para AN, pero ninguna relación con AP. Conforme esperado, apertura no mostró relación con AP y AN. Estos resultados están de acuerdo con la literatura internacional, pero algunas diferencias importantes fueron detectados.
\end{abstract}

Palabras clave: personalidad, afecto, bienestar, big five, neuroticismo

Positive affect (PA) and negative affect (NA) constitute the emotional dimension of subjective well-being and are

\footnotetext{
'Article based on the first author's doctoral dissertation, under the supervision of the last author. This dissertation was defended in 2011 at the Universidade Federal do Rio Grande do Sul. Support: National Council for Scientific and Technological Development (CNPq) and Coordination for the Improvement of Higher Education Personnel (CAPES).

2 Correspondence address:

Cristian Zanon. Universidade São Francisco. Rua Alexandre Rodrigues Barbosa, 45, Centro. CEP 13251-900. Itatiba-SP, Brazil. E-mail: cristianzanon@yahoo.com.br
}

characterized by the frequency and intensity that subjects are prone to feel positive and negative emotions such as joy, excitement, anger, and sadness. Because Positive Psychology (Snyder \& Lopez, 2005) has focused on understanding what makes people happier (Lyubomirsky, 2001), investigations regarding affects have been extensively conducted, and personality is suggested as an important predictor of affects (Hayes \& Joseph, 2003). High levels of NA are positively associated with depression, anxiety, and rumination (NolenHoeksema, 1991; Nolen-Hoeksema，2000; Trapnell \& 
Campbell, 1999), while high levels of PA are positively related with job and marital satisfaction and physical health (Naragon \& Watson, 2009). The aims of this study were to evaluate the relationships between positive and negative affect and personality, to compare these results with the ones provided by the literature, and to add further ideas to the scientific community.

Positive and negative affects are orthogonal factors (Diener $\&$ Emmons, 1985) that contribute directly to the perception of well-being. Subjective well-being (Diener, Suh, Lucas, \& Smith, 1999) is composed by two dimensions, one affective and the other cognitive. The latter, called life satisfaction, is a subjective judgment based on an individual's perception about his/her life as a whole. The former is a balance between PA and NA in an individual's life. More PA (than NA) can lead to the conclusion that life is good (Lucas \& Diener, 2008). These authors claim that affects may have the function of showing whether life is going well or not (through rewards or punishments), however, they may also serve as the motivation for people to make adjustments or try harder to achieve their goals.

According to Diener and Larsen (1984), people tend to feel their affects in a stable way. This does not mean that people with high levels of positive affect will not feel negative emotions or vice-versa. Extreme mood changes might take place over a short period of time, however, most of the time people will present stable affect scores, that can be the result of genetic influences (Lyubomirsky, King, \& Diener, 2005). In fact, some studies (Lykken \& Tellegen, 1996; Nes, Roysamb, Tambs, Harris, \& Reichborn-Kjennerud, 2006) have indicated that the variance and stability over time of happiness and subjective well-being are moderately explained by genetic heritance. This does not mean that they are immutable (Lucas \& Diener, 2008). The idea is that, in general, people will return to their normal levels of affects after some time, for example, after the negative event or situation has passed (Diener, 1994). However, not everybody has similar patterns of oscillations. Some people present large fluctuations in their positive and negative affect levels over time, while others are more stable (Gadermann \& Zumbo, 2007). These authors suggest that these fluctuations might be due to personality differences.

The way people perceive and interpret events, thoughts, and feelings in their life is modeled by personality traits (McCrae \& Costa, 2008). Consequently, the frequency and intensity of PA and NA that individuals might feel probably depend on the way they perceive and elaborate the events in their lives.

A ubiquitous model used to study the relationships between affects and personality is the Big Five (McCrae \& Costa, 1997), which is a descriptive model that conceptualizes personality from five factors: Neuroticism, Extraversion, Agreeableness, Conscientiousness and Openness. Each factor is indicated by "very basic tendencies (abstract psychological potentials) that can be inferred from behavior and experience" (McCrae \& Costa, 2008). The factors are composed by facets that represent the combination of specific personality traits that describe behaviors, attitudes, preferences, and feelings. These factors, facets and traits suggest a hierarchical structure that has been replicated over time and in different cultures (John, Naumann, \& Soto, 2008).

Personality is considered stable over time (Roberts \& DelVecchio, 2000) and also influenced by genetics (Tellegen et al., 1988), as well as well-being. Therefore, if the hypothesis that claims that personality models the way people feel their affects is true, it would be expected that personality factors and affects share a considerable amount of variance. Costa and McCrae (1980) proposed a model in which extraversion leads to PA and neuroticism leads to NA. This study motivated new investigations in the area and these results were replicated (Emmons \& Diener, 1985; Hepburn \& Eysenck, 1989), with the possible explanation for this being that: (a) extroverts are more cheerful and high-spirited than introverts, or (b) people with high levels of neuroticism are more prone to feel negative affect than those with low levels.

Later, McCrae and Costa (1991) hypothesized that agreeableness and conscientiousness would somehow predict well-being because loving and hard-working people would have more PA and less NA than people with low levels of these factors. The reason for this suggestion is due to these people possibly being more social and having more achievementrelated success. This instrumental hypothesis states that the characteristics present in people with high levels of agreeableness and conscientiousness might influence wellbeing indirectly through the way people cope with specific situations, related to work and relationships, for example. In fact, the authors found that PA was positively correlated to agreeableness and conscientiousness, and that NA presented the opposite relationship with these personality measures. In addition, openness presented weak correlations with affects, suggesting that the other factors are far more relevant to predict well-being.

DeNeve and Cooper (1998) conducted a meta-analysis summarizing the majority of the research available at that time, in order to estimate the importance of personality for subjective well-being. Their findings suggested that the relationships between these concepts were much weaker than expected. For example, the authors showed correlations of .20 (4\% of shared variance) between extraversion and PA, and 23 (approximately $5 \%$ of shared variance) between neuroticism and NA. Ten years later, a new meta-analysis suggested that personality is much more relevant to subjective well-being than was shown before (Steel, Schmidt, \& Shultz, 2008). Specifically, these authors found that extraversion explained $19 \%$ of positive affect variance ( $28 \%$ disattenuated) and that neuroticism explained $29 \%$ of negative affect variance ( $41 \%$ disattenuated).

Regarding agreeableness and conscientiousness, Steel et al. (2008) noted that they presented correlations with affects that were significantly different from zero, which means that these factors somehow play constant and relevant roles in the way people feel their emotions. The authors attribute these huge differences between their meta-analysis and that 
of DeNeve and Cooper (1998) to commensurability. In other words, the use of many different tests to evaluate personality and affects might have reduced the correlations in DeNeve and Cooper's study. The effect of different tests investigating the same or similar constructs was intentionally addressed in the other investigation in which the authors only considered studies based on the measures used.

Considering that a large amount of personality variance is due to genetics and that there is evidence that well-being is mostly determined by genetics, to find strong relationships between personality and the affective components of subjective well-being (SWB) corroborates the hypotheses that (a) they both have common predictors, (b) that SWB is a stable construct (Steel et al., 2008), and (c) SWB is modeled somehow by the personality. In addition, to evaluate how much each personality factor predicts positive and negative affect variance (using tests developed for the studied population - Brazilian undergraduate students) might corroborate the literature cited or require new explanations about these relationships. The aims of this study were: (a) to gauge how much positive and negative affect variances (estimated as a latent trait) are predicted by the five personality factors and (b) to estimate what the individual contribution is of each factor to both positive and negative affect using a hybrid structural regression model (part path model and part confirmatory factor analysis). This method has the advantage of reducing the error of measurement of the variables (affects) during the estimation process, the same does not happen with correlations/regressions (Kline, 2011).

\section{Method}

\section{Participants}

Participants were 319 university students of all areas, of a major university in Southern Brazil, middle class, aged between 17 and 37 years, with the mean age being 21.5 years $(S D=4.9)$. Approximately $64 \%$ of the students were female and $36 \%$ male. The sample was chosen by convenience and the students took part on a voluntary basis.

\section{Instruments}

The following instruments were used:

Factorial Personality Battery - FPB (Nunes, Hutz, \& Nunes, 2010): A self reported instrument, composed of 126 items and modeled on the Five Factor Model. This scale allows for a fast and objective evaluation of the big five dimensions of human personality i.e., Extraversion, Neuroticism, Agreeableness, Conscientiousness, and Openness. This test was developed for the Brazilian population and is not an adaptation of a foreign test. It was constructed based on personality descriptors used by Brazilians (Hutz et al., 1998) and comprises part of the content and structure of other available Brazilian factorial personality scales used to assess Neuroticism (Hutz \& Nunes, 2001), Extraversion (Nunes
\& Hutz, 2006), Agreeableness (Nunes \& Hutz, 2007) and Openness (Vasconcellos \& Hutz, 2008).

The factors are composed by different numbers of facets and items, and do not correspond to the same facets as the most famous international personality tests. Extraversion is comprised by four facets: communication, haughtiness, dynamism, and social interactions. Neuroticism is comprised by four facets: vulnerability, depression, emotional instability, and passivity. Agreeableness is comprised by three facets: amiability, sociability, and people trust. Conscientiousness is comprised by three facets: competency, prudency, and commitment. Openness is comprised by three facets: interest in new ideas, liberalism, and novelty seeking. Though the differences between the PFB and other personality tests highlight the problem of commensurability (that can make it difficult or even impossible to compare these results with others), it has the advantage of reflecting an actual/original and appropriate structure of the Big Five, totally configured for Brazilians. In this sense, the results provided by this test might show tendencies or particularities that have to be analyzed from a cultural perspective, when international comparisons are intended.

The facets are calculated through the mean of the specific items and each factor is a mean of the facets. Items in the PFB are constructed in the form of sentences that describe the attitudes, beliefs and feelings of participants. They are answered on a seven-point Likert type scale where 1 equates to 'does not describe me at all' and 7 to 'describes me completely'. The PFB presents adequate internal consistency - alpha coefficient - for each of the factors: Neuroticism .89, Extraversion .84, Agreeableness .85, Conscientiousness .83, and Openness .74.

Affect Scale (Zanon, Bastianello, Pacico, \& Hutz, 2013): This self reported test that evaluates affects as traits, was constructed based on the PANAS-X (Watson \& Clark, 1994) and on the Brazilian adapted version of PANAS (Giacomoni \& Hutz, 1997). The content of the items was defined after a content validity study conducted with university students that described important and frequent emotions in their life. The Affect Scale presented convergent validity with the Brazilian version of PANAS. Strong correlations between positive $(r=.73)$ and negative $(r=.74)$ affect items were found. This test is composed of 20 items ( 10 for positive affects and 10 for negative affects) answered on a five-point Likert type scale where 1 equates to 'does not describe me at all' and 5 to 'describes me completely'. The items are sentences (instead of adjectives) that describe past and present feelings and emotions. Adequate internal consistencies - alpha coefficient - for the positive (.83) and negative (.77) items were found.

To estimate PA and NA as latent variables, a technique known as parceling (Little, Cunningham, Shahar, \& Widaman, 2002) was used with the Affect Scale. Parceling items allows the reduction of the number of parameters to be estimated in the model and also provides more stable indicators. Because structural equation modeling is sensitive to parsimony, to have a measurement model with fewer indicators is appropriate for 
estimating latent variables when researchers are not interested in information at the item level.

To parcel the items, three groups of items were created for each affect, based on content similarity. The items were summed. Two groups were formed by three items and one group by four. Therefore, positive and negative affect were estimated as latent variables through three indicators each.

\section{Procedure}

Data collection. Participants collectively completed the questionnaires whilst in the classrooms. The participants were asked to carefully read the questions and respond to the items according to their personal feelings. Data collection was performed in a single session for each class of students. The students first completed the affect scale and then the personality scale. The total time taken to complete the test was approximately 40 minutes.

Data analysis. Initially, descriptive statistics and correlations among the variables of interest were analyzed. After the inspection of these results, we evaluated a hybrid structural model to estimate how personality factors predict affects. Goodness of fit evaluation was based on the model chisquare, the root mean square error of approximation (RMSEA), the comparative fit index (CFI), and the standardized root mean square residual (SRMR). Analyses were conducted using the LISREL 8.8 program (Maximum Likelihood method).

\section{Ethical Considerations}

The ethical aspects of the study were guaranteed in compliance with Resolution 196 regarding research involving human beings (Ministério da Saúde, 1996). This research project was approved by the Research Ethics Committee of the Universidade Federal do Rio Grande do Sul under protocol number 2010001. Prior to commencing the study, the students were informed that their participation was voluntary, and that all information shared would remain confidential.

\section{Results}

Table 1 presents the descriptive statistics and correlations between the variables studied. Clearly, some patterns can be observed. Neuroticism presented moderate positive correlations with the three negative affect variables and weak negative correlations with the three positive affect ones. Extraversion showed weak positive correlations with the positive affect variables and basically no correlations with the negative affect variables. Agreeableness presented weak negative correlations with the negative affect variables and weak positive correlations with two of the positive affect variables. Conscientiousness correlated significantly (positively) with just one negative affect variable and with two positive affect variables (weak and also positive). Openness presented very weak positive correlations with the three positive affect variables and no correlations with the negative ones.

To estimate how much the five factors together explain the positive and negative affect variance, as well as how much each factor explains this independently, a hybrid structural model (Figure 1) was proposed. The circles are the latent variables. The squares on the left side represent the independent variables, and those on the right side are indicators of the latent variables.

As can be seen, two indicators showed that the model presented an adequate fit: $\mathrm{CFI}=.092, \mathrm{SRMR}=.055$. The others did not support (or partially supports) its fit: $\chi^{2}$ $(29)=121.71, p<.001$, and RMSEA $=.096$. The model chi-square is a sample-dependent index and usually presents significant results in large samples, therefore no conclusion about model fit should rely exclusively on this. The RMSEA is a parsimony adjusted index that favors simpler models. As the purpose was to evaluate the role of each personality factor in both affective variables, and not just to evaluate

Table 1

Descriptive Statistics and Correlations Between Personality Factors and Affects

\begin{tabular}{|c|c|c|c|c|c|c|c|c|c|c|c|}
\hline Variables & Neuroticism & Extraversion & Agreeableness & Conscientiousness & Openness & PA1 & PA2 & PA3 & NA1 & NA2 & NA3 \\
\hline 1- Neuroticism & - & & & & & & & & & & \\
\hline 2- Extraversion & -.17 & - & & & & & & & & & \\
\hline 3-Agreeableness & -.31 & .01 & - & & & & & & & & \\
\hline 4- Conscientiousness & -.22 & .01 & .26 & - & & & & & & & \\
\hline 5- Openness & .01 & .41 & -.06 & -.02 & - & & & & & & \\
\hline 6- Positive Affect 1 & -.38 & .32 & .01 & .27 & .20 & - & & & & & \\
\hline 7- Positive Affect 2 & -.34 & .31 & .12 & .30 & .11 & .56 & - & & & & \\
\hline 8- Positive Affect 3 & -.31 & .31 & .28 & .07 & .17 & .36 & .49 & - & & & \\
\hline 9- Negative Affect 1 & .52 & -.03 & -.26 & .01 & .01 & -.15 & -.06 & -.22 & - & & \\
\hline 10- Negative Affect 2 & .39 & -.03 & -.12 & .10 & .01 & -.14 & -.16 & -.17 & .33 & - & \\
\hline 11- Negative Affect 3 & .49 & -.05 & -.21 & -.01 & .06 & -.12 & -.16 & -.35 & .51 & .51 & - \\
\hline Mean & 3.4 & 4.3 & 5.1 & 4.8 & 4.6 & 14.9 & 12.4 & 12.4 & 11.4 & 7.7 & 8.8 \\
\hline SD & .8 & .8 & .7 & .7 & .8 & 2.9 & 2.0 & 2.1 & 3.8 & 2.5 & 2.8 \\
\hline
\end{tabular}

Note. PA1 $=$ Positive Affect 1 ; PA2 = Positive Affect 2 ; PA3 = Positive Affect 3; NA1 = Negative Affect 1; NA2 = Negative Affect 2; NA3 $=$ Negative Affect 3 . 


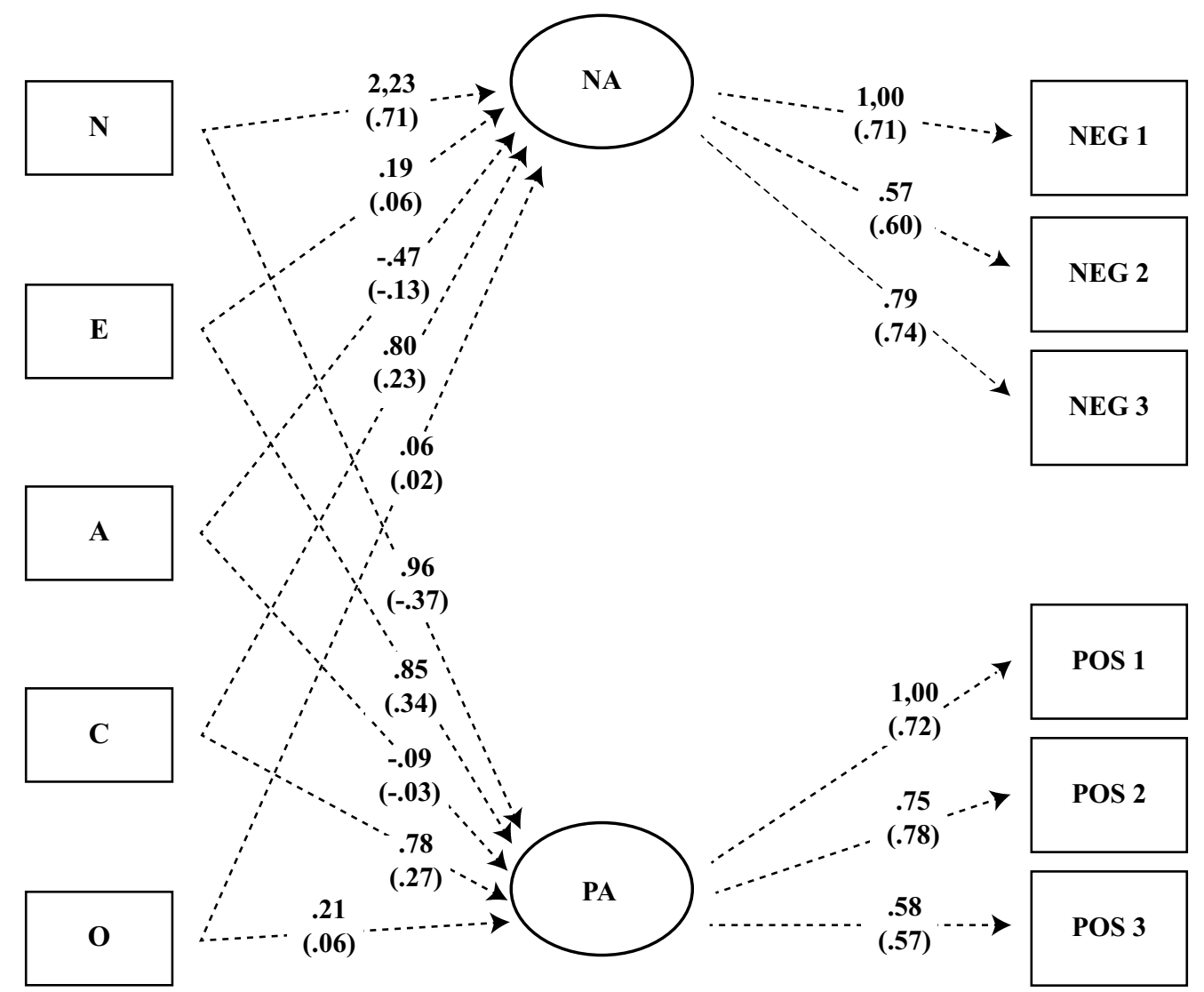

Figure 1. Model evaluated to assess the relations between personality and affects.

which model best explains the affect variances, the poor fit of approximation suggested for this index might not represent a serious violation of the model fit for this study.

The values presented in the model are non-standardized and those in parentheses standardized. Regarding the standardized solution, the estimates between personality factors and affects represent standardized regression coefficients (beta) controlling for the other variables. For example, the increase of one standard deviation in neuroticism is associated with a .71 standard deviation increase in NA and .37 standard deviation decrease in PA. Following this reasoning, extraversion presents basically no association with NA and a moderate association (.34) with PA. Agreeableness shows no relationship with PA and a weak and negative relationship with NA (-.13). Conscientiousness presented positive relationships with PA (.27) and NA (.23). Openness did not present a relationship with either affect. The numbers between the latent variables and their indicators (in parenthesis) are interpreted as factor loadings, and the numbers on the right of the indicators are standardized errors of measurement. The amount of positive and negative affect variance predicted by the five personality factors was $43.3 \%$ and $53.4 \%$ respectively.

\section{Discussion}

Personality factors are important predictors of affects and should be integrated into any theory that concerns subjective well-being (Lucas \& Diener, 2008). In this study, the five personality factors together explained a large proportion of the positive and negative affect variance in a different culture, and using different measures (these instruments were developed based on the same theoretical background that others used in the international literature).

Neuroticism was clearly the most relevant predictor of NA. Controlling for the other factors, one standard deviation increase in neuroticism is associated with a 7 standard deviation increase in NA. Astrong association between these variables was expected and suggests that the way emotionally unstable people perceive their life events might have a direct impact on their well-being. One possible mediator of this relationship is rumination (not included in this study). According to Lyubomirsky, Caldwell and Nolen-Hoeksema (1998), rumination might be the thinking style that neurotic people use more and that triggers a chain of negative thoughts. To consciously think about negative events might be closely associated with feeling such as sadness, guilty, and shame, among others (Nolen-Hoeksema, 2000). Therefore, rumination can be one of the links that connect the tendency to be depressive, passive, and vulnerable (some facets that define Neuroticism) with negative affects.

Neuroticism presented an inverse and moderate relationship with PA. This result might reflect some overlap of items with opposite content regarding depression, instability and vulnerability (Araújo, 2002) and some items of the positive affect scale that explore constructs such as bravery, strength, 
and confidence. Therefore, it possibly means that, more than just increasing NA, neuroticism might also decrease PA. Similar results were found in another Brazilian university sample using different personality and affect instruments (Zanon \& Hutz, 2010, Zanon \& Hutz, 2013). These findings indicate that emotional instability ought to aggregate the most relevant characteristics, and have the greatest power to predict wellbeing. Regarding the high level of association of neuroticism with PA and NA found, it is suggested that interventions focused on increasing well-being should consider techniques that reduce rumination and promote self-reflection, such as distraction and meditation (Papageorgiou \& Wells, 2004).

The relationship found between Extraversion and PA also corroborates the literature (Costa \& McCrae, 1980; McCrae \& Costa, 1991). However, the almost null association with negative affect suggests that the basic tendencies to be communicative, dynamic, and to seek social interactions, do not protect subjects against the perception and development of negative emotions. Considering that traits influence how people interpret situations (John et al., 2008), Extraversion might play an important role in the way people interpret life events and consequently feel their positive emotions. It is possible that extroverted people tend to view the world in a more favorable way, and often bias their interpretations in order to favor themselves. The opposite pattern might be found in neurotic people. For this reason, extroverted people might perceive themselves as happy and neurotic people may perceive themselves as unhappy.

Agreeableness basically showed no relationship with PA. Despite the very small correlations found with two of the parceled groups of items, no predictive power was found in the model. This result suggests that tendencies such as being sympathetic, caring about people, and trusting them, ought to not be necessarily motivated by positive rewards, as the participants with these characteristics did not presented high levels of PA. Conversely, a weak negative relationship with NA suggests that agreeableness might play a role in wellbeing through a less negative interpretation of situations. Regarding the instrumental hypothesis (McCrae \& Costa, 1991), these results only partially support this. It is possible that people with high agreeableness scores cope better with events related to academic achievement and better tolerate negative feedback, however, there is little evidence to indicate that such skills increase positive emotions.

Another possibility, as stated by McCrae and Costa (1991) in the instrumental hypothesis, is that people with high scores in both agreeableness and conscientiousness ought to present increased well-being. In fact, a moderate positive relationship between conscientiousness and PA supports the assumption that to be hard working, organized and persistent is associated with more positive affects. In this sense, Bartley and Roesch (2011) found that conscientiousness serves as a protective factor from stress when associated with problem-focused coping.

Contrary to expectations, a positive relationship between conscientiousness and NA indicates that, together, characteristics such as prudency, commitment, and competency might also be associated with more negative emotions. According to Cianci, Klein and Seijts (2010), students with high conscientiousness scores may feel more pressure to achieve the challenges presented to them compared with individuals with low levels of conscientiousness. In addition, these authors found that highly conscientious students showed higher levels of tension when dealing with negative feedback than students with low levels of conscientiousness. Such results illustrate a reasonable explanation for this contradictory finding. Therefore, it is possible that very capable students express anxiety symptoms when faced with academic adversities. Other possible explanations for this may be: 1) perfectionist students are more vulnerable to anxiety, 2) they do not enjoy successfully completed things, and 3) they possibly feel unsatisfied with their achievements.

Openness did not present a relationship with either PA or NA. Despite not being new, some explanations are given for these results. Possibly, novelty seeking and interest for new ideas, two of the facets measured by the FPB, are motivated by a natural tendency to become bored with repetitive activities and a desire to achieve important goals. Therefore, engagement in the patterns of behavior related to these facets can produce satisfaction, however, not necessarily. It is possible that novelty seeking only alleviates boredom for many people and that interest for new ideas satisfies epistemic interests, without being related to enjoyment. Regarding the other facet, liberalism, to be conservative or liberal can equally be associated with PA and NA. However, it cannot be assumed that both groups have similar levels of well-being, and for this reason studies focused on the mechanisms that underlie these variables are important.

One limitation of this study is that the participants were students who presented high levels of education, and were mostly young adults from southern Brazil. Therefore, these results should be interpreted with caution and should not be extrapolated to the general population. However, the relationships found between personality and affects corroborate international findings and therefore may be similar with other Brazilian samples from different regions and social classes.

\section{Conclusion}

The use of a hybrid model to evaluate the relationships between personality and affects corroborated the stable relationships between neuroticism and negative affect, and extraversion and positive affect. Unexpectedly, neuroticism predicted higher levels of positive affect than extraversion and indicated the predominance of neuroticism for SWB. The lack of association between agreeableness and positive affect, as well as the negative relationship between conscientiousness and positive affect were also unexpected. These findings might represent a sample idiosyncrasy or show some particularity of the Brazilian student population. Therefore, new studies 
focusing on the association of these variables, using other samples of different regions and ages might support or contradict the findings presented in this article.

\section{References}

Araújo, A. F. (2002). Percepção dos estilos educativos parentais e ajustamento psicológico do adulto: Comparação entre indivíduos com e sem perturbações depressivas. Paidéia (Ribeirão Preto), 12(24), 215-227. doi:10.1590/S0103-863X2002000300010

Bartley, C. E., \& Roesch, S. C. (2011). Coping with daily stress: The role of conscientiousness. Personality and Individual Differences, 50(1), 79-83. doi:10.1016/j.paid.2010.08.027

Cianci, A. M., Klein, H. J., \& Seijts, G. H. (2010). The effect of negative feedback on tension and subsequent performance: The main and interactive effects of goal content and conscientiousness. Journal of Applied Psychology, 95(4), 618-630. doi: 10.1037/a0019130

Costa,P.T., \& McCrae, R.R.(1980). Influence of extraversionand neuroticism on subjective well-being: Happy and unhappy people. Journal of Personality and Social Psychology, 38(4), 668-678. doi:10.1037/0022-3514.38.4.668

DeNeve, K. M., \& Cooper, H. (1998). The happy personality: A meta-analysis of 137 personality traits and subjective well-being. Psychological Bulletin, 124(2), 197-229. doi:10.1037/0033-2909.124.2.197

Diener, E. (1994). Assessing subjective well-being: Progress and opportunities. Social Indicators Research, 31(2), 103157. doi:10.1007/BF01207052

Diener, E., \& Emmons, R. A. (1985). The independence of positive and negative affect. Journal of Personality and Social Psychology, 47(5), 1105-1117. doi:10.1037/0022-3514.47.5.1105

Diener, E., \& Larsen, R. J. (1984). Temporal stability and crosssituational consistency of affective, behavioral, and cognitive responses. Journal of Personality and Social Psychology, 47(4), 871-883. doi:10.1037/0022-3514.47.4.871

Diener, E., Suh, E. M., Lucas, R. E., \& Smith, H. S. (1999). Subjective well-being: Three decades of progress. Psychological Bulletin, 125(2), 276-302. doi:10.1037/0033-2909.125.2.276

Emmons, R. A., \& Diener, E. (1985). Personality correlates of subjective well-being. Personality and Social Psychology Bulletin, 11(1), 89-97. doi:10.1177/0146167285111008

Gadermann, A. M., \& Zumbo, B. D. (2007). Investigating the intra-individual variability and trajectories of subjective well-being. Social Indicators Research, 81(1), 1-33. doi:10.1007/s11205-006-0015-x

Giacomoni, C. H., \& Hutz, C. S. (1997). A mensuração do bem-estar subjetivo: Escala de afeto positivo e negativo e escala de satisfação de vida [Resumos]. Anais do Congresso Interamericano de Psicologia, 26, 313.
Hayes, N., \& Joseph, S. (2003). Big 5 correlates of three measures of subjective well-being. Personality and Individual Differences, 34(4), 723-727. doi:10.1016/S0191-8869(02)00057-0

Hepburn,L.,\&Eysenck,M.W.(1989).Personality, averagemood and mood variability. Personality and Individual Differences 10(9), 975-983. doi:10.1016/0191-8869(89)90062-7

Hutz, C. S., \& Nunes, C. H. S. S. (2001). EFN: Escala Fatorial de Ajustamento Emocional/Neuroticismo. São Paulo, SP: Casa do Psicólogo.

Hutz, C. S., Nunes, C. H. S. S., Silveira, A. D., Serra, J., Anton, M., \& Wieczorek, L. S. (1998). O desenvolvimento de marcadores para a avaliação da personalidade no modelo dos cinco grandes fatores. Psicologia: Reflexão e Crítica, 11(2), 395-411. doi:10.1590/S0102-79721998000200015

John, O. P., Naumann, L. P., \& Soto, C. J. (2008). Paradigm shift to the integrative big-five trait taxonomy: History, measurement, and conceptual issues. In O. P. John, R. W. Robins, \& L. A. Pervin (Eds.), Handbook of personality: Theory and research (3rd ed., pp. 114-158). New York, NY: Guilford.

Kline, R. B. (2011). Principles and practice of structural equation modeling ( $3 \mathrm{rd}$ ed.). New York, NY: Guilford.

Little, T. D., Cunningham, W.A., Shahar, G., \& Widaman, K. F. (2002). To parcel or not to parcel: Exploring the question, weighing the merits. Structural Equation Modeling, 9(2), 151-173. doi:10.1207/S15328007SEM0902_1

Lucas, R. E., \& Diener, E. (2008). Personality and subjective well-being. In O. P. John, R. W. Robins, \& L. A. Pervin (Eds.), Handbook of personality: Theory and research (3rd ed., pp. 795-814). New York, NY: Guilford.

Lykken, D., \& Tellegen, A. (1996). Happiness is a stochastic phenomenon. Psychological Science, 7(3), 186-189. doi:10.1111/j.1467-9280.1996.tb00355.x

Lyubomirsky, S. (2001). Why are some people happier than others? The role of cognitive and motivational processes in well-being. American Psychologist, 56(3), 239-249. doi:10.1037/0003-066X.56.3.239

Lyubomirsky, S., Caldwell, N. D., \& Nolen-Hoeksema, S. (1998). Effects of ruminative and distracting responses to depressed mood on retrieval of autobiographical memories. Journal of Personality and Social Psychology, 75(1), 166-177. doi:10.1037/0022-3514.75.1.166

Lyubomirsky, S., King, L., \& Diener, E. (2005). The benefits of frequent positive affect: Does happiness lead to success? Psychological Bulletin, 131(6), 803-855. doi:10.1037/0033-2909.131.6.803

McCrae, R. R., \& Costa, P. T., Jr. (1991). Adding Liebe and Arbeit: The full five-factor model and well-being. Personality and Social Psychology Bulletin, 17(2), 227232. doi:10.1177/014616729101700217

McCrae, R. R., \& Costa, P. T., Jr. (1997). Personality trait structure as a human universal. American Psychologist, 52(5), 509-516. doi:10.1037/0003-066X.52.5.509 
McCrae, R. R., \& Costa, P. T., Jr. (2008). The five-factor theory of personality. In O. P. John, R. W. Robins, \& L. A. Pervin (Eds.), Handbook of personality: Theory and research (3rd ed., pp. 159-181). New York, NY: Guilford.

Naragon, K., \& Watson, D. (2009). Positive affectivity. In S. J. Lopez (Ed.), Encyclopedia of positive psychology (Vol. 2, pp. 707-711). Malden, MA: Wiley-Blackwell.

Nes, R. B., Roysamb, E., Tambs, K., Harris, J. R., \& Reichborn-Kjennerud, T. (2006). Subjective well-being: Genetic and environmental contributions to stability and change. Psychological Medicine, 36(7), 1033-1042. doi:10.1017/S0033291706007409

Nolen-Hoeksema, S. (1991). Responses to depression and their effects on the duration of depressive episodes. Journal of Abnormal Psychology, 100(4), 569-582. doi:10.1037/0021-843X.100.4.569

Nolen-Hoeksema, S. (2000). The role of rumination in depressive disorders and mixed anxiety/depressive symptoms. Journal of Abnormal Psychology, 109(3), 504-511. doi:10.1037/0021-843X.109.3.504

Nunes, C. H. S. S., \& Hutz, C. S. (2006). Development and validation of an extraversion scale in the big five personality model. Psico-USF, 11(2), 147-155. doi:10.1590/S1413-82712006000200003

Nunes, C. H. S. S., \& Hutz, C. S. (2007). Construção e validação da escala fatorial de socialização no modelo dos cinco grandes fatores de personalidade. Psicologia: Reflexão e Crítica, 20(1), 20-25. doi:10.1590/S0102-79722007000100004

Nunes, C. H. S. S., Hutz, C. S., \& Nunes, M. F. O. (2010). BFB: Bateria fatorial de personalidade: Manual técnico. São Paulo, SP: Casa do Psicólogo.

Papageorgiou, C., \& Wells, A. (2004). Depressive rumination: Nature, theory and treatment. Chichester, England: John Wiley \& Sons.

Roberts, B. W., \& DelVecchio, W. F. (2000). The rank-order consistency of personality traits from childhood to old age: Aquantitative review of longitudinal studies. Psychological Bulletin, 126(1), 3-25. doi:10.1037/0033-2909.126.1.3

Snyder, C. R., \& Lopez, S. J. (2005). Handbook of positive psychology. New York, NY: Oxford University Press.

Steel, P., Schmidt, J., \& Schultz, J. (2008). Refining the relationship between personality and subjective well-being. Psychological Bulletin, 134(1), 138-161. doi:10.1037/0033-2909.134.1.138

Tellegen, A., Lykken, D., Bouchard, T. J., Wilcox, K. J., Segal, N. L., \& Rich, S. (1988). Personality similarity in twins reared apart and together. Journal of Personality and Social Psychology, 54(6), 1031-1039. doi:10.1037/0022-3514.54.6.1031

Trapnell, P. D. \& Campbell, J. D. (1999). Private SelfConsciousness and the Five-Factor Model of personality: Distinguishing rumination from reflection. Journal of Personality and Social Psychology, 76, 284-304.
Vasconcellos, S. J. L., \& Hutz, C. S. (2008). Construção e validação de uma escala de abertura à experiência. Avaliação Psicológica, 7(2), 135-141.

Zanon, C., Bastianello, M. R., \& Hutz, C. S. (2013). Desenvolvimento e validação de uma escala de afetos positivos e negativos. Psico-USF, 18(2), 193-202.

Zanon, C., \& Hutz, C. S. (2010). Relações entre bem-estar subjetivo, neuroticismo, ruminação, reflexão e sexo. Gerais: Revista Interinstitucional de Psicologia, 2, 118-127.

Zanon, C., \& Hutz, C. S. (2013). Affective disposition, thinking styles, neuroticism and life satisfaction. Universitas Psychologica, 12(2), 403-411.

Watson, D., \& Clark, L. A. (1994). The PANAS-X manual for the positive and negative affect schedule - expanded form. Iowa City, IA: The University of Iowa. Retrieved from http:// www.psychology.uiowa.edu/faculty/clark/panas-X.pdf

Cristian Zanon is a Professor at the Institute of Psychology of the Universidade São Francisco.

Micheline Roat Bastianello is a Ph.D. candidate of the Universidade Federal do Rio Grande do Sul.

Juliana Cerentini Pacico is a Ph.D. candidate of the Universidade Federal do Rio Grande do Sul.

Claudio Simon Hutz is a Professor at the Institute of Psychology of the Universidade Federal do Rio Grande do Sul.

Received: Aug. $4^{\text {th }} 2012$

$1^{\text {st }}$ Revision: Feb. $27^{\text {th }} 2013$

$2^{\text {nd }}$ Revision: Apr. $5^{\text {th }} 2013$

Approved: Apr. 24 2013

How to cite this article:

Zanon, C., Bastianello, M. R., Pacico, J. C., \& Hutz, C. S. (2013). Relationships between positive and negative affect and the five factors of personality in a Brazilian sample. Paidéia (Ribeirão Preto), 23(56), 285-292. doi: 10.1590/1982-43272356201302 